\title{
SOME CARE, LITTLE RESPONSIBILITY? PROMOTING DIRECTORS' AND MANAGERS' LEGAL ACCOUNTABILITY FOR OCCUPATIONAL HEALTH AND SAFETY IN THE WORKPLACE
}

\author{
KAREN WHEELWRIGHT
}

[Health and safety at work remains a serious and under-recognised problem in Australia. This paper argues for the importance of increasing the individual responsibility and accountability of senior managers and directors of corporations for the development and maintenance of occupational health and safety (OHS) standards in the workplace. In order to do so, the paper first sets out the range of statutory and general law duties and liabilities to which directors and senior managers are subject, considers to what extent these obligations have relevance in the OHS area and argues for the extension of these duties and liabilities in some circumstances. The paper then goes on to argue for a better legislative model for the legal responsibility of managers and officers, supported by the increased prosecution of individuals in appropriate circumstances, as well as acknowledging the benefits of a broader range of non-legal strategies to improve boardlevel commitment to OHS that will influence corporate compliance overall.]

\footnotetext{
${ }^{*}$ Lecturer, Deakin Law School.
} 


\section{The Legal Response to the Problem of Workplace INJURIES AND FATALITIES}

The role and effectiveness of the law in promoting workplace health and safety warrants continued scrutiny because workplace deaths and injuries remain a serious social and economic problem in Australia. In its report in October 2003, the Productivity Commission estimated that work-related deaths, injuries and illnesses cost individuals, the community and the economy in excess of $\$ 30$ billion annually. In addition, said the Commission, 'injured workers and their families face the accompanying pain and suffering'. ${ }^{1}$ With respect to injuries, the Industry Commission in 1995 estimated that at any one time, more than 200,000 people could not work at all due to an injury or disease sustained at work, and a further 260,000 had been forced to change jobs or reduce working hours due to work-related injury. ${ }^{2}$

Deaths and injuries at work are largely avoidable. Research indicates that, far from being mostly 'acts of God' or the result of worker carelessness, their causes are more often attributable to 'management failures, systems breakdowns, and the neglect by organisations, their senior officers and workers to take health and safety as seriously as they should'. ${ }^{3}$

To address the problem, all states and territories, and the Commonwealth, have specific purpose OHS statutes that place a general duty on employers to ensure that the workplace is safe and without risks to health. ${ }^{4}$ Occupational health and safety statutes in Australia are broadly similar in approach, due at least in part to the profound influence of the 1972 Robens report on the design of British and (in the 1980s) Australian OHS legislation, which is still being felt today. ${ }^{5}$ All of the statutes encourage organisations to identify OHS problems specific to their workplaces, and design and implement systems and strategies to reduce or eliminate risk. They impose duties on a range of persons whose actions may affect the safety of the workplace, including employers, employees, manufacturers and importers of plant and equipment and suppliers of chemicals.

The author acknowledges with thanks the helpful comments on a draft of this paper by Colin Fenwick, Director, Centre for Employment and Labour Relations Law, the University of Melbourne, and Dr Fiona Haines, Department of Criminology, the University of Melbourne, as well as the helpful comments of the anonymous referee.

${ }^{1}$ INDUSTRY COMMISSION, NATIONAL WORKERS' COMPENSATION AND OCCUPATIONAL HEALTH AND SAFETY FRAMEWORKS INTERIM REPORT 20 (2003).

${ }^{2}$ INDUSTRY COMMISSION, WORK, HEALTH AND SAFETY Xviii (1995).

3 Andy Hall, Richard Johnstone, Alexa Ridgeway, Reflection On Reforms: Developing

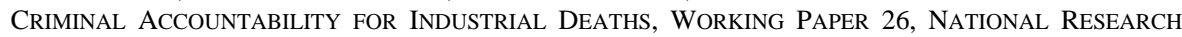
CENTRE FOR OHS REGULATION 11 (2004).

${ }^{4}$ See Occupational Health and Safety Act, 2004 (Vic); Occupational Health and Safety Act, 2000 (NSW); Occupational Safety and Health Act, 1984 (WA); Workplace Health and Safety Act, 1995 (Qld); Workplace Health and Safety Act, 1995 (Tas); Occupational Health, Safety and Welfare Act, 1986 (SA); Work Health Act, 1986 (NT), Occupational Health and Safety (Commonwealth Employees) Act 1991. The Commonwealth has no direct constitutional power over occupational health and safety matters, except with respect to its own employees, but plays an advisory and co-ordinating role through the National Occupational Health and Safety Commission.

${ }^{5}$ REPORT OF THE COMMITTEE ON SAFETY AND HEALTH AT WORK 1970-72 (ROBENS REPORT) (1972). 
In all jurisdictions, the legislation provides for the monitoring and investigation by specific-purpose government agencies of workplace adherence to OHS laws. These agencies place a strong emphasis on the provision of information and guidance to assist employers to meet their statutory obligations. This guidance may be informal, or may take the form of codes of practice that address specific hazards and issues and that may have evidentiary weight in prosecutions. The statutes also provide for non-prosecutorial mechanisms to promote compliance (such as the issue of written notices requiring a safety breach to be remedied), as well as for prosecutions for the failure to meet statutory health and safety obligations. Breaches of the legislation may be summary or indictable offences depending on the act in question, but it is common for all but the most serious indictable offences to be tried summarily.

As well as OHS legislation, there are other ways in which the law could be said to promote good OHS practices. The employer's common law duty of care to provide a safe workplace is still argued to have an important deterrent effect, as well as meeting its primary aim of providing damages to workers who have been injured as a result of a breach of that duty. ${ }^{6}$ The workers' compensation schemes may also have some deterrent effect on unsafe work practices, as insurance premiums are often related to the cost of previous claims and the level of risk of the industry in which the employer operates.

DIRECTORS' AND MANAGERS' LIABILITY FOR OHS FAILURES UNDER THE GENERAL LAW

The OHS statutes are the principal source of directors' and managers' individual liability for OHS failures. In most cases individual liability is dependent upon proof of employer (organisational) liability. Directors of corporations and persons concerned in the management of corporations may be prosecuted. Before considering these statutory liabilities in more detail, it is useful to consider the degree to which officers and senior managers may be accountable for safety breaches under the civil and the general criminal law.

\section{A Civil liability}

The law has long-recognised that employers have a duty of care at common law for the health and safety of their workers. ${ }^{7}$ Where the employer is a company, it is the company itself, rather than the individuals who own and operate it, that owes the duty of care. The duty is not owed by individual directors or employees, and this

\footnotetext{
${ }^{6}$ See eg Workers Online, Issue no 102, July 2001, available at <www.labour.net.au> (last visited 31 March 2005). It is important to note, however, that right of an employee to sue his or her employer in negligence has been abolished or seriously curtailed in most Australian jurisdictions, in favour of statutory workers' compensation claims.

${ }^{7}$ Wilsons and Clyde Coal Co v English, [1938] AC 57 (Eng. H. of L 1938).
} 
principle holds even in the case of a company that is a one-person company. ${ }^{8}$ This follows directly from the separate legal entity principle articulated in Salomon $v$ Salomon \& Co. ${ }^{9}$ The principle was reiterated by the High Court in the recent case of Andar Transport Pty Ltd v Brambles Ltd, where the court stated that "[T]he common law duty to take reasonable care for the safety of employees is imposed directly on Andar by virtue of its status as an employer. The duty is not imposed upon individual directors of a corporate employer.' ${ }^{10}$

There have been a small number of negligence cases where the courts have held that a director is personally liable for torts committed in the course of the company's business. A director may be liable, for example, if he or she procures or directs the commission of a tort, or if he or she assumes personal responsibility for the performance of a duty. ${ }^{11}$ In the area of workplace deaths, it may be possible for a director to act towards an employee of the company in such a way that they can be said to have legally assumed personal responsibility towards the employee so as to create a special relationship, although there appear to be no cases where the issue has been raised explicitly in the workplace safety context. ${ }^{12}$

Commentators on the case law argue that no coherent set of principles has developed for attributing personal liability to directors for negligently-caused losses. ${ }^{13}$ In the light of this, and given the settled tort law principles about the employer's duty of care, it would appear highly unlikely that the law of tort would develop so as to place general liability on directors in the workplace safety area.

\section{B Directors' duties}

The duties owed by directors in equity and under corporations legislation are not owed to third parties like employees. Directors' duties are owed to the company and are concerned with protecting the financial interests of its shareholders and, in certain narrowly defined circumstances where the company is at risk of insolvency, its creditors. ${ }^{14}$

However, ensuring a company provides a safe working environment for its employees is arguably encompassed by a director's duty to act honestly in the best interests of the company, either in equity or under s 181(1)(a) of the Corporations Act 2001 (Cth). This is because poor OHS systems are not in the company's best interests -

\footnotetext{
${ }^{8}$ Always assuming that the company is not a sham: Lee v Lee’s Air Farming Ltd, [1961] AC 12, 26 (Eng. H. of L. 1961, per Lord Morris).

${ }^{9}$ [1897] AC 22 (Eng. H. of L, 1897).

${ }^{10}$ [2004] HCA 28, para [49] (High Court of Australia, 2004).

${ }^{11}$ See eg Wah Tat Bank Ltd v Chan, [1975] AC 507 (Eng. H. of L 1975); Trevor Ivory Ltd v Anderson, [1992] 2 NZLR 517.

${ }^{12}$ CENTRE FOR CORPORATE ACCOUNTABILITY, RESPONSE TO HOME OFFICE CONSUltation DoCUMENT 'REFORMing THE LAW ON INVOLUnTARY MANSLAUghter ThE GOVERNMENTS PROPOSALS' 3.27 (2000).

${ }^{13}$ Helen Anderson, The Theory of the Corporation and Its Relevance to Directors' Tortious Liability to Creditors, 16 AUST J CORP L 73 (2004).

${ }^{14}$ Spies v R, (2000) 201 CLR 603 (High Court of Australia, 2000).
} 
they demonstrably affect a company adversely through lost time, higher workers' compensation premiums, the possibility of penalties under OHS legislation, and the adverse publicity that may follow a serious workplace accident. Nevertheless, there are no judicial statements that even hint that such an interpretation of this fiduciary obligation might develop in the courts. We could posit several reasons for this. As OHS obligations are addressed expressly by statute, and have been so for over a hundred years, judges may see no need to duplicate them by way of an expanded and novel interpretation of the duty to act in the 'interests of the company'. More importantly, such a novel expansion would run counter to the central concern of the courts in developing and interpreting directors' duties over a long period of time, which is to protect proprietary rights. As the Senate Standing Committee observed in its 1989 report Company Directors' Duties (the Cooney report), '[c]ompany case law provides a slender basis for extending directors' duties to anyone other than the company and those who have proprietary interests in it: the shareholders and, in certain circumstances, creditors'. ${ }^{15}$

The obvious means by which directors' duties can be extended is by way of express provisions in the Corporations Act 2001 (Cth), or by way of positive duties in OHS legislation. In 1989, a Senate Standing Committee was asked to consider whether such an extension was warranted as part of its general review of directors' duties. The Committee recommended that the 'companies legislation be amended to make it clear that the interests of a company's employees be taken into account by directors in administering the company'. ${ }^{16}$ The Committee believed that the narrow approach company law has traditionally taken was difficult to reconcile with contemporary reality. This is still true today and is evidenced by, amongst other things, the continuing interest by many in promoting corporate social responsibility towards stakeholders affected by the company's operations, and towards the community generally and the environment. The Committee's recommendation was never acted upon. The issue is being revisited, however, with the Parliamentary Secretary to the Treasurer asking the Corporations and Markets Advisory Committee to inquire into corporate responsibility and triple-bottom-line reporting. The Committee has been asked to inquire, amongst other things, into 'the extent to which the current legal framework governing directors' duties encourages or discourages them from having regard for the interests of stakeholders other than shareholders, and the broader community'. ${ }^{17}$

It is possible to anticipate the difficulties posed by a proposal to include a statutory duty upon directors and senior managers to take account of employee interests generally. The precise scope and content of such a duty would be contentious and questions would be raised about the difficulties that arise when a duty to employees

\footnotetext{
15 Senate Standing Committee on Legal and Constitutional AfFairs, Company Directors DUTIES: REPORT ON THE SOCIAL AND FIDUCIARY OBLIGATIONS OF COMPANY DIRECTORS (THE COONEY REPORT), PARA 6.3 (1989).

${ }^{16}$ Id. Recommendation 8, at xii.

${ }^{17}$ PARLIAMENTARY JOINT COMMITTEE ON CORPORATION S AND FINANCIAL SERVICES, INQUIRY INTO CORPORATE RESPONSIBILITY, TERMS OF REFERENCE, at <www.aph.gov.au/senate/committee/corporations_ctte> (accessed 28 July 2005).
} 
conflicts with a duty to shareholders. ${ }^{18}$ However, a positive duty to ensure effective OHS management in the interests of the corporation's workers (perhaps included in OHS legislation) would pose fewer difficulties of definition and scope. The most important consideration in arguing for a positive legal duty in the OHS sphere is the considerable capacity of directors to ensure good OHS management systems in their companies, in the same way that directors have the capacity to ensure the financial health and solvency of their companies through instituting and supervising proper financial management systems. Ultimate responsibility for occupational health and safety rests with top management; the commitment of senior managers and directors is fundamental to the success of health and safety management. ${ }^{19}$ Inquiries into disasters such as the Zeebrugge ferry sinking have identified the central role played by directors in the failure of corporate systems leading to disaster. ${ }^{20}$ Corporate activities can pose serious risks to workers or the public; when they do, good public policy demands that these risks be regulated. The price the corporation and its controllers pay for the freedom to do business is that 'the conduct of the regulated actor will comply with and maintain a certain minimum standard of care'. ${ }^{21}$

\section{Employment obligations of senior managers}

There are no specific principles of contract or equity that promote accountability for OHS by senior employees of companies. Senior managers and chief executive officers are employees of the company and the employment relationship is also a recognised fiduciary relationship. ${ }^{22}$ By analogy with directors' fiduciary duties, a senior manager's obligation is to act in the interests of the employer company and is not a duty owed to employees.

Many companies, particularly larger ones, appoint managers with specific powers and duties to manage the company's occupational health and safety program. The manager's failure to do so with due skill and care will be a breach of his or her employment contract, giving the employer the right to discipline or dismiss the manager, depending on the terms of the contract an the circumstances of the breach. This is a matter of private contract law and privity of contract; the manager owes no duty to the employees who may be affected by his or her breach of contract, and

\footnotetext{
${ }^{18}$ A simple example would be the encouragement by directors of a friendly takeover that would advantage shareholders, but would be likely to lead to worker redundancies.

${ }^{19}$ See CENTRE FOR CORPORATE ACCOUNTABILITY, supra note 12, where the comments of the Health and Safety Executive and the British Standards Association to this effect are set out; see also Michael Quinlan, Managing Occupational Health and Safety in a Changing Environment, in NEW DIRECTIONS IN OCCUPATIONAL HEALTH AND SAFETY PROSECUTIONS (Richard Johnstone ed., 1996).

${ }^{20}$ See CENTRE FOR CORPORATE ACCOUNTABILITY, supra note 12.

${ }^{21}$ R v Wholesale Travel Group Inc, [1991] 3 SCR 154; 4 OR (3D) 799 (Supreme Court of Ontario, 1991).

${ }^{22}$ Hospital Products Ltd v United States Surgical Corporation, (1984) 156 CLR 41 (High Court of Australia, 1984). The extent of an employee's obligation to act in the interests of the employer will depend on the seniority of the employee and the nature of his or her position. Senior managers have more extensive fiduciary obligations than do junior employees: see Colour Control Centre Pty Ltd v Ty, Supreme Court of NSW, 1689/93, unreported, 24 July 1995.
} 
incurs no liability to them, unless the circumstances are such that the manager's actions constitute a criminal offence or a regulatory offence under OHS legislation (discussed further below).

\section{Criminal law}

There are very limited circumstances in which a senior manager or director might be liable under the general criminal law in Australia when a worker is killed or is seriously injured. The possible charges would be manslaughter by gross (or criminal) negligence in the case of a death at work, or negligently causing serious injury (with the wording of the relevant offences differing slightly in the criminal statutes from state to state).

The criminal standard is set out in Nydam $v R$, where the essence of manslaughter was stated to involve a great falling short of the standard of care which a reasonable person would have exercised, involving such high risk that death or grievous bodily harm would follow that the doing of the act merited criminal punishment. ${ }^{23}$ The standard applies to situations where the defendant commits a positive act (such as requiring an employee to drive a truck, knowing that the truck had seriously faulty brakes, which resulted in the employee's death when the truck went out of control on a downhill slope). ${ }^{24}$ The application of the law is more difficult when the death results from management's failure to act, for example, by negligently failing to assess workplace risk and to ensure safe working procedures. In such cases, proof of the charge requires proof that the individual manager owed a duty of care to the deceased, that the defendant breached the duty, and that the departure from the proper standard of care was such as to warrant criminal punishment. ${ }^{25}$

Other ways in which individual directors or managers may be held to have a duty to a deceased or seriously injured worker is by personally procuring, directing or authorising the company to commit the unlawful act that caused the death, or by acting towards the deceased so as to indicate that he or she undertakes a personal duty towards him or her. ${ }^{26}$ These circumstances are much more likely to be satisfied in very small companies, leaving the personnel in larger companies that have more complex management structures with the protection of the corporate veil.

In practice, there have been very few prosecutions and convictions of individuals (or corporations) for criminal offences in the workplace or public safety context in Australia. ${ }^{27}$ There has been a stronger trend in Britain over the last few years to

\footnotetext{
${ }^{23}$ Nydam v R, [1977] VR 430, 445 (Supreme Court of Victoria, 1977).

${ }^{24}$ These were the facts of The Queen v Denbo and Another, (Supreme Court of Victoria, 14 June 1994). The company pleaded guilty to manslaughter, in exchange for the DPP dropping the manslaughter charge against one of the two directors (who together effectively ran the company).

${ }^{25} \mathrm{R}$ v Bateman,[1925] All ER 79. For a detailed discussion, see Hall, Johnstone, Ridgeway, supra note 3, at 32- 33 .

${ }^{26}$ Hall, Johnstone, Ridgeway, supra note 3, at 33, and the sources cited there.

${ }^{27}$ Id., at $12-14$.
} 
prosecute individual directors and managers for manslaughter, although the numbers are, proportionally, still small. ${ }^{28}$

\section{Industrial manslaughter offences}

The problems of common law liability can be overcome by statutory criminal offences specifically designed for the industrial context. There has been an ongoing debate in Australia, the UK, Canada and other countries for a decade about the need for more effective provisions to enable the prosecution of corporations and officers where the negligent conduct of company operations leads to the deaths of workers or members of the public.

The Australian Capital Territory is the only jurisdiction to make industrial manslaughter offences part of the mainstream criminal law. Under the Crimes (Industrial Manslaughter) Act 2003 (ACT), senior officers may be found guilty of industrial manslaughter only in very narrowly-defined circumstances - their acts or omissions must substantially contribute to the death of a worker and the senior officer's conduct must be either reckless or negligent. Penalties for breach are a fine up to $\$ 200,000$ or imprisonment up to 20 years, or both. The offence is so narrowly constructed that it is highly unlikely it will ever be prosecuted; this reduces the deterrent effect the provisions might otherwise have. ${ }^{29}$

The ACT formulation is considerably narrower than the proposed senior officer offence in the failed Victorian Crimes (Workplace Deaths and Injuries) Bill 2001. In that Bill, a senior officer could be liable where the corporation had committed an offence, and the officer was 'organisationally responsible' for the conduct that resulted in the death or serious injury, and the officer materially contributed to its commission..$^{30}$ It is submitted that this formulation is preferable to the very narrow one in the ACT legislation because it recognises the important responsibility senior officers have for OHS at the organisational level, whilst still requiring proof that the accused officer materially contributed to the death or serious injury.

Some states have 'industrial manslaughter' type offences in their OHS statutes, or provide for higher penalties where death or serious injury results from a safety failure. These offences are discussed further below.

\footnotetext{
${ }^{28}$ Supra note 3.

${ }^{29}$ Ronald MCCallum, P Hall, A Hatcher, A SEArle, AdVice in Relation to WorkPlace Death, OCCUPATIONAL HEALTH AND SAFETY LEGISLATION AND OTHER MATTERS paras 42 - 49 (2004).

${ }^{30}$ Karen Wheelwright, Prosecuting corporations and officers for industrial manslaughter- recent Australian developments, 32 AUSTRALIAN BUS. L. REV. 239, 248 (2004). The Bill never became law.
} 


\section{E Directors' and managers' statutory liability for OHS failures}

State occupational health and safety legislation is the principal source of legal liability for individuals, although neither the Commonwealth nor ACT legislation provides for individual liability of officers or managers. ${ }^{31}$ The individuals to whom liability attaches in the remaining statutes include directors and other company officers, executive officers, persons 'involved in the management' of the corporation, and employees, with slight differences amongst the provisions in the precise groups of individuals to whom liability may attach. Some of the newer provisions apply to 'persons', indicating that they are not confined to corporate officers and managers. ${ }^{32}$ As with employer liability under OHS legislation, the liability is criminal rather than civil. Penalties are predominantly fines, but imprisonment is available for some offences under the Victorian, Western Australian and NSW acts. ${ }^{33}$

The liability of individual directors and managers under OHS laws is generally dependent upon breach of duty by the employer. The employer is the primary duty holder under OHS legislation, not least because the employer 'has the means to be able to promote the observance of this statutory objective' ${ }^{34}$ Given that the vast majority of employers are incorporated, this is in practice a duty on incorporated business undertakings to provide, so far as is practicable, a working environment that is safe and without risks to health. ${ }^{35}$ The employer's duty is personal and nondelegable. ${ }^{36}$ About $90 \%$ of prosecutions are of employers. ${ }^{37}$

In practice, the employer's duty can be implemented only through the acts of individuals - the directors, managers and employees of the employer company. Research has indicated a strong link between management commitment to OHS and good OHS practice in organisations. In the view of one expert, the first principle of the five principles of good OHS management is demonstrated senior management commitment to OHS:

It is impossible to conceive of an effective OHS management regime where senior management is not committed to this goal. Without such a commitment it is extremely unlikely either that resources and time will be

\footnotetext{
${ }^{31}$ The names of the statutes are set out supra note 4 .

${ }^{32}$ See eg s 32 Occupational Heath and Safety Act 2004 (Vic).

${ }^{33}$ The new 'industrial manslaughter' offences in the NSW act provide for imprisonment instead of, or as well as a fine.

${ }^{34}$ Broken Hill Associated Smelters Pty Ltd v Stevenson, [1991] 42 IR 130, 145.

${ }^{35}$ This is the wording in s 21(1) of the OHS Act 2004 (Vic). The wording varies slightly from state to state. For a comprehensive comparison, see R JOHNSTONE, OCCUPATIONAL HEALTH AND SAFETY LAW AND POLICY, ch 4 (2004).

${ }^{36}$ Workcover Authority of New South Wales v Thiess Pty Ltd, [2003] NSWIRComm 45 (New South Wales Industrial Relations Commission, 2003); Linework Ltd v Department of Labour, [2001] 2 NZLR 639 (Supreme Court of New Zealand, 2001).

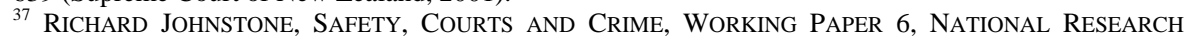
CENTRE FOR OHS REGULATION, 8 (2002).
} 
devoted to the issue or that lower levels of management will treat the matter seriously.

The other four principles are as follows:

- OHS management is integrated into core management and work activities

- OHS management uses a systems approach

- The OHS management system addresses change

- The management system values worker input. ${ }^{38}$

Clearly each principle requires strong management commitment and positive action for its successful implementation.

Can statutory liability provisions play a part in promoting management commitment to good OHS practice in organisations? To answer the question, it is important to consider in a little more detail the rationale for individual liability.

\section{THE RATIONALE FOR INDIVIDUAL LIABILITY}

\section{A The individual liability debate}

Legislation that places duties and imposes liabilities on corporations also commonly imposes liabilities on those individuals who direct and manage them. As well as occupational health and safety legislation, there are individual liability provisions in general corporations legislation, trade practices legislation and environmental protection legislation, to name just a few. Concerns are expressed from time to time by the business community and others that the range of statutory liabilities may result in inconsistent compliance burdens and increased costs for business, or that they may provide disincentives for directors to accept or continue to hold directorships. Such concerns prompted a reference by the federal government in July 2002 to the Corporations and Markets Advisory Committee, requesting it to inquire into and make recommendations about the extent of directors' liability under federal legislation. ${ }^{39}$

These general concerns are not universally shared. In a recent report, the Australian Law Reform Commission considered that the principles of individual liability, in federal legislation at least, are clearly articulated in individual statutes and 'do not appear to create any particular difficulties’ ${ }^{40}$ The Commission did acknowledge,

\footnotetext{
${ }^{38}$ Michael Quinlan, Managing Occupational Health and Safety in a Changing Environment, in NEW Directions in Occupational HeAlth and SAFETy PROSECUTiOns 22-28. (Richard Johnstone ed.,1996)

${ }^{39}$ See <http://www.camac.gov.au/camac/camac.nsf>. The Committee produced a discussion paper 'Personal Liability for Corporate Fault' in May 2005, with submissions on the paper closing in August 2005.

${ }^{40}$ AUSTRALIAN LAW REFORM COMMISSION, REPORT 95 PRINCIPLED REGULATION para [8.35] (2002).
} 
however, that important issues were raised by those statutes that deemed individuals liable for a contravention by the corporation simply on the basis that the individual is involved in management, without the need to prove individual fault.

A further argument against wide-ranging officer and manager liability is that it erodes the protection given to directors and managers, thereby discouraging the use of companies as vehicles for economic activity, particularly by small businesses. ${ }^{41}$ It needs to be remembered, however, that limited liability was provided to protect investors, not directors. Although in the 'small business' company investors and directors may be the same persons, the assumption that the protection of directors by the corporate form and limited liability is a natural and desirable consequence of the use of the corporate form for business activities is a questionable one.

Can individual legal duties and liability provisions be justified in the OHS regulatory regime? The usual justifications for imposing criminal liability on individual officers and managers in the OHS area include: that this achieves specific and general deterrence, that it meets the community's sense of justice, and that it is necessary to avoid some of the practical difficulties in implementing regulatory regimes against corporations. Properly-drafted provisions with supporting guidance may also positively encourage individuals to meet their obligations, rather than operating only negatively. The research evidence about the effectiveness of individual liability provisions in meeting these aims is in some respects equivocal and confusing (see below), but there are nevertheless good reasons for imposing liability on individuals within corporations.

\section{Deterrence}

In deterrence theory, the formal legal system is the essential element in the crime inhibition process. This is important as the primary purpose of prosecution of both organisations and individuals for OHS offences is deterrence, both general and specific. ${ }^{42}$ It follows then that 'fear of detection, arrest and punishment resulting from conviction forms the core of a deterrence model' ${ }^{43}$ In the legal regulation of corporate activities, the deterrence model assumes that corporations and their officers are rational actors who make calculated choices on a cost-benefit analysis about whether or not to comply with criminal laws. ${ }^{44}$ It follows that the less likely detection and prosecution are in practice, the less effective these laws are likely to be as a deterrent of undesirable behaviour. ${ }^{45}$

\footnotetext{
${ }^{41}$ N HAWKE, CORPORATE LIABILITY (2000).

${ }^{42}$ HALL, JOHNSTONE, RIDGEWAY, supra note 3, at 8.

${ }^{43}$ SALly Simpson, Corporate CRIME, LAW AND SOCIAL CONTROL 9 (2002).

${ }^{44}$ The assumption of rational behaviour is not borne out by some empirical studies, which show that many other factors are at play. See eg Terry Makkai \& John Braithwaite, The Dialectics of Corporate Deterrence, 31 JOURNAL OF RESEARCH IN CRIME AND DELINQUENCY 347 (1994).

${ }^{45}$ It is important to bear in mind that Australian authorities prosecute only a tiny proportion of breaches of OHS laws. In 1995, the Industry Commission calculated that the expected penalty for an OHS offender (individual and corporate) was less than \$33, taking into account the likelihood that a breach
} 
Other research shows that for some officers and managers, the mere possibility of individual prosecution and punishment may have the desired deterrent effect, and so we cannot necessarily assume that low levels of prosecution in practice dilute the law's deterrent effect. Some Australian research into individual OHS offending has indicated that when managers distinguish between prosecutions of corporate entities and prosecutions of individual directors and managers, it is the possibility of individual liability 'which is by far the most important motivating factor ...personal liability [is the issue] about which directors express most concern and which ... motivates the compliance program more than anything else'. ${ }^{46}$

The nature of penalties appears to be important in deterrence. Officers of corporations continued to be concerned about the possibility of imprisonment under environmental legislation eight years after tough new penalties were introduced, in spite of the fact that no senior officers had been convicted of a serious offence or imprisoned. This concern motivated their compliance with environmental audits and due diligence obligations. ${ }^{47}$ Penalties such as fines, imprisonment, probation, community service orders, disqualification of directors and adverse publicity 'may have a very considerable specific and general deterrent effect on individual managers and directors' ${ }^{48}$ There is support for the effectiveness of individual criminal sanctions in improving corporate behaviour more generally. The Australian Law Reform Commission considered that generally individual liability encourages greater transparency in management processes and improves accountability and performance standards of the organisations which the individuals manage. ${ }^{49}$ Academics have also argued that the imposition of liability, particularly criminal liability, on individual directors and managers may be an important spur to improved corporate governance in organisations. ${ }^{50}$

The deterrent effect of individual liability provisions in regulatory law, including OHS law, is complicated by the complex relationship between the corporation and individual actors within it. In her book Corporate Crime, Law and Social Control, Simpson argues that managers are socialized into organisational goals and a manager's decision to knowingly break the law 'may be supported by operational norms and organizational subcultures. ${ }^{51}$ Perceptions of organisational needs have been shown empirically to influence the corporate offending decision. Illegality is not pursued for individual benefits but for organisational ends; the decisions of individual managers are affected by organisational contingencies, priorities and needs,

would be detected, prosecuted and punished: see the discussion in NEIL GUNNINGHAM AND RICHARD JOHNSTONE, REgULATING WORKPLACE SAFETY: SYSTEMS AND SANCTIONS 187 (1999).

${ }^{46}$ Andrew Hopkins, Making Prosecutions More Effective in OCCUPATIONAL Health AND SAfETy PROSECUTIONS IN AUSTRALIA: OVERVIEW AND ISSUES (Richard Johnstone ed, 1994).

${ }^{47}$ GUNNINGHAM \& JOHNSTONE, supra $\mathrm{n} 45$, at 188-189.

48 JOHNSTONE, supra n 35, at 427.

${ }^{49}$ ALRC, above n 40.

${ }^{50}$ Jennifer Hill, Corporate Criminal Liability in Australia: An Evolving Corporate Governance Technique? in J. Bus. L. 1 [2003]. Hill's main focus was on the new forms of liability in the Criminal Code Act, 1995 (Cth).

${ }^{51}$ SimPSON, supra $\mathrm{n} 43$, at 7. 
rather than personal needs. Accordingly, in order to understand whether corporate crime is amenable to deterrence, 'one needs to examine how managers experience and express the moral imperatives of their work environment and how organisational needs are formulated and inculcated into managerial decisions'.52

Whilst the deterrent effect of the law on corporate officer offending is clearly a complex area, we should not abandon the notion that individual liability provisions can have a positive effect on OHS compliance by organisations. We do need to acknowledge however:

that there are different types of organisations, with different organisational structures and decision-making processes, with the result that criminal sanctions will differ in their deterrent impact upon the organizations and the individuals within them. ${ }^{53}$

It is also important to recognise that individuals in organisations, like individuals outside of them, are motivated to comply with the law for reasons other than fear of criminal prosecution and punishment. These factors include moral habituation, threats to reputation and employment status, friendship and family attachment. Traditional deterrence neglects these kinds of controls, although they can be recognised in compliance strategies that do not rely heavily on prosecution of offenders. ${ }^{54}$

\section{Social condemnation and 'just deserts'}

Community perceptions of the seriousness of corporate crime have increased over time, with $74 \%$ of respondents to a recent US survey ranking worker health and safety crimes to be serious. ${ }^{55}$ The agitation over the last 10 years for more effective principles of corporate liability, particularly in the general criminal law, reflects this change in perception.

Individual accountability and punishment may be as important, if not more important, than corporate accountability in expressing the social condemnation and 'just deserts' functions of the law, and to satisfy public demands for retribution, particularly in areas where deaths or serious injuries of workers or members of the public have resulted from organisational and individual management failure or neglect. ${ }^{56}$ The corporation, after all, has 'no soul to damn, and no body to kick', and the most common penalty, a monetary fine, cannot be guaranteed to have the necessary deterrent and punitive effect, particularly for a well-resourced corporation. Even with the development of more creative and effective corporate penalties, such as publicity orders, community service orders, equity fines and enforceable undertak-

\footnotetext{
${ }^{52} I d$., at 7- 9.

${ }^{53}$ GUNNINGHAM \& JOHNSTONE, supra n 45, at 190.

${ }^{54}$ SIMPSON, supra n 43, 9-10, ch 6.

${ }^{55}$ Id., at 3.

${ }^{56}$ Celia Wells, Corporate killing, NEW L. J. 1467, 1467 (1997).
} 
ings, individual accountability may still reflect more effectively the community perception that justice is being done. ${ }^{57}$

\section{Practical problems with reliance on corporate liability}

Finally, the availability of prosecution of individuals within corporations is important, because targeting the corporation alone has shortcomings. The flexibility of the corporate form can pose a danger that a company may be wound up and its fines not paid. ${ }^{58}$ The artificial nature of the corporation means that it is resistant to the effect of the usual range of criminal penalties; obviously it cannot be imprisoned, but as already noted, even heavy fines may have little or no effect on a wellresourced company. Some companies indeed budget for them as one of the usual costs of doing business. They can also be readily passed on to others, such as consumers of the company's goods and services. The development of a more creative range of penalties will go some way to addressing this problem. ${ }^{59}$

It does not follow that individual liability should therefore replace corporate liability. A system based around individual liability alone also has problems, not least of which is the ability of larger corporations in particular, if they are inclined to do so, to make it difficult if not impossible for investigators to identify culpable individuals when there is a safety failure (or, conversely, to direct blame to certain individuals who are not necessarily solely culpable, because of internal company politics). There may also be situations where there are no individuals who can be said to be sufficiently culpable to warrant prosecution - the safety failure may be the result of the interplay of various acts or omissions of numerous individuals and groups. Individual liability alone will be inadequate in such cases, unless we adopt a model that deems individuals CEOs and directors automatically liable because of a safety failure by the organisation, without the benefit of any due diligence defences. There must be a balance between corporate and individual liability.

\section{FORMS OF INDIVIDUAL LIABILITY UNDER THE OHS STATUTES}

\section{A Overview}

In all but the ACT and the Commonwealth, OHS legislation provides for the prosecution of individual managers and officers for the failure to have safe and healthy workplaces. The legislation has been described generally as 'piercing the corporate veil and attributing a form of primary liability, concurrently with the corporation, to

\footnotetext{
${ }^{57}$ Harry Glasbeek, Criminal Law as a Political Tool, 11 AUST. J. LABOUR L. 95 (1998).

${ }^{58}$ This happened in The Queen v Denbo Pty Ltd, (unreported, Supreme Court of Victoria 14 June 1994),

where a company pleaded guilty to manslaughter but wound up in insolvency, leaving the fine unpaid.

${ }^{59}$ JoNATHAN CLOUGH \& CARMEL MULHERN, THE PROSECUTION OF CORPORATIONS, ch 5 (2002).
} 
its directors and managers' ${ }^{60}$ In addition, three states provide for additional offences or penalties for individuals where a safety breach involves recklessness, gross negligence or results in death or serious injury to a worker.

The forms of individual liability differ somewhat from state to state; this contrasts with the duties imposed upon employers, which are reasonably consistent across the different statutes. At the very least, this poses problems for companies that operate in different states. It may also indicate a lack of clarity amongst policy makers and legislators working in the same area about what is the most desirable and effective form of individual liability.

In summary, the main forms of liability are as follows:

\section{1 officer consents or connives in corporation's offence, or offence due to officer's neglect}

This form of individual liability appears in the Work Health Act 1986 (NT) (s 180) and the Occupational Safety and Health Act 1984 (WA) (s 55). ${ }^{61}$ Where an offence against the Act is committed by a body corporate, the officer or manager is also guilty where the offence was committed with his or her consent, connivance or as a result of his or her neglect, or 'wilful neglect'. The burden falls on the prosecution to establish that the officer consented, connived or demonstrated the necessary degree of neglect.

\section{2 officer is deemed to have contravened the Act if the corpora- tion has contravened, subject to defences}

The best example of this form is in the Occupational Health and Safety Act 2000 (NSW) (s 26). This section provides that, where a corporation contravenes, whether by act or omission, any provision of the Act or regulations, each director/manager is taken to have contravened the same provision, unless the person satisfies the court that:

a) he or she was not in a position to influence the conduct of the corporation in relation to its contravention of the provisions; or

b) he or she, being in such position, used all due diligence to prevent the contravention by the corporation.

The burden of proof in the NSW act is on the director or manager, on the balance of probabilities. The Authority cannot rely on a successful prosecution of the corporation to secure a penalty against a director or other individual referred to in that section; the individual must be proceeded against separately from the corporation.

\footnotetext{
${ }^{60}$ Harold Ford, R P Austin, I M Ramsay, Company Directors: Principles of LAW AND CORPORATE GOVERNANCE, 610 (12 ${ }^{\text {th }}$ ed., 2005).

${ }^{61}$ A similar offence appeared in s 53 of the OHS Act 1985 (Vic).
} 
However, the director or manager may be found guilty whether or not the corporation has been proceeded against or found guilty. ${ }^{62}$

Section 167 of the Workplace Health and Safety Act 1995 (Qld) provides that the executive officers of a corporation must ensure that the corporation complies with the Act. Evidence that the corporation has been convicted of an offence against a provision of the Act is evidence that each of the executive officers committed the offence of 'failing to ensure that the corporation complies with the provision' (s 167(3)). As with the NSW provisions, it is a defence for an executive officer to prove that he or she was not in a position to influence the corporation's conduct, or, being in such a position, 'exercised reasonable diligence to ensure the corporation complied with the provision' (s 167(3) - (4)).

A broadly similar offence appears in s 53 of the Workplace Health and Safety Act 1995 (Tas). The Tasmanian provision applies only to directors (but the Tasmanian act also has 'responsible officer' provisions - see below). A director has available the defence of 'all due diligence', as well as the defence that the body corporate contravened the provision without the director's knowledge and that the director was not reasonably able to acquire that knowledge.

\section{3 officer contravenes Act where body corporate's contraven- tion is attributable to an officer failing to take reasonable care}

This approach is exemplified by s 144 of the new Occupational Health and Safety Act 2004 (Vic). This form of liability is quite different from NSW and Queensland in that the onus remains on the prosecution to establish beyond reasonable doubt that the body corporate's contravention 'is attributable to an officer of the body corporate failing to take reasonable care'(s 144(1)). The burden is not on the officer to show due diligence. In determining whether an officer is guilty of an offence, regard must be had to:

a) what the officer knew about the matter concerned; and

b) the extent of the officer's ability to make, or participate in the making of, decisions that affect the body corporate in relation to the matters concerned; and

c) whether the contravention by the body corporate is also attributable to an act or omission of any other person; and

d) any other relevant matter. ${ }^{63}$

Like NSW, the officer can be proceeded against only if the body corporate has contravened a provision of the Act of regulations, although the officer may be convicted whether or not the body corporate has been proceeded against or found guilty (s 144(1), 144(4)).

\footnotetext{
${ }^{62}$ Veisis v Stand By Two Pty Ltd, (1993) 49 IR 432 (Marks J); OHS Act 2000, (NSW), s 26(2)

${ }^{63}$ See s 144(3).
} 


\section{4 'responsible officer' contravenes if he or she fails to take reasonable steps to ensure corporation's compliance}

Both the South Australian and Tasmanian acts require the appointment of 'responsible officers'. Under s 61 of the Occupational Health, Safety and Welfare Act 1986 (SA), the corporation must appoint one or more responsible officers who must take reasonable steps to ensure compliance by the body corporate with its obligations under the Act. If no responsible officer is appointed, each officer of the body corporate is deemed to be a responsible officer. A responsible officer is not deemed to have contravened the Act if the body corporate contravenes, but it is an offence for a responsible officer not to take reasonable steps to ensure the body corporate's compliance.

Section 10 of the Workplace Health and Safety Act 1995 (Tas) requires the employer (which is apparently not confined to bodies corporate) to appoint someone with sufficient authority to perform the employer's duties at each of the employer's workplaces. The employer is to ensure that a responsible officer has sufficient authority to perform the duties of a responsible officer. In the absence of an appointed responsible officer, the person responsible for the direction and management of the business is deemed to be appointed as the responsible officer. It is a contravention if the responsible officer' fails to 'perform the duties of his or her employer under this Act at the workplace for which he or she is the responsible officer'. A number of defences are available, including that it was not reasonably practicable for the responsible officer to perform that duty; or the failure to perform the duty was due to causes over which the responsible officer had no control, or the responsible officer used all due diligence 'to prevent the failure to perform the duty' (s 11).

\section{$5 \quad$ Offences tied to the result of the safety breach}

The new Occupational Health and Safety Amendment (Workplace Deaths) Act 2005 (NSW) introduces a new offence of 'reckless conduct causing death at the workplace by a person with OHS duties' for both corporations and individuals. Individuals will be guilty of the new offence if they engage in conduct that causes the death of another person, have an obligation under the OHS Act 2000 (NSW) for the health and safety of that person, and are reckless about the danger of death or serious injury to the person to whom that duty is owed. ${ }^{64}$ The OHS Act 2004 (Vic) introduces a new offence of recklessly engaging, without lawful excuse, in conduct that places or may place another person who is at a workplace in danger of serious injury (s 32) ${ }^{65}$ In other acts, penalties are heavier where the safety breach results in death or serious injury (see further below).

\footnotetext{
${ }_{65}^{64}$ Occupational Health and Safety Amendment (Workplace Deaths) Act 2005, Schedule 1.

${ }^{65}$ The wording of the offence is such that it is not aimed just at officers and managers.
} 


\section{B Other provisions}

Each of the OHS statutes imposes duties on employees which may, at least in theory, apply to managers and chief executives of companies. For example, the Victorian Act imposes on employees a duty (amongst other things) to 'take reasonable care for the health and safety of persons who may be affected by the employee's acts or omissions at workplace' (s 25((1)(b)). On a plain reading, these provisions could be used to prosecute defaulting managers, but it is unclear how likely this will be. Such provisions have been used to prosecute supervisors however. ${ }^{66}$ A senior manager might be prosecuted under the new s 32 of the Victorian act in appropriately egregious circumstances.

\section{Penalties for individuals}

The principal penalty for individuals convicted of the 'director/manager' offences outlined is a fine, but increasingly imprisonment is an option where the safety breach results in death.

The maximum fine varies considerably depending on the legislation in question. Currently, the highest fines are provided in the new Victorian Act, which provides for a maximum fine of $\$ 184,050$ where the body corporate's contravention of the duty to provide a safe workplace (s 21) is attributable to the officer's failure to take reasonable care. In Victoria, breach of s 32 is a maximum fine of \$184,050, as well as, or instead of, a maximum of 5 years' imprisonment.

Increasingly, fines are linked to the seriousness of the result of the safety breach. Under the Queensland Act, an individual may be fined up to $\$ 150,000$ where the offence causes multiple deaths. The Western Australian legislation provides for fines up to $\$ 250,000$ for a first offence and up to $\$ 312,500$ for a subsequent offence in the case of the most serious offences (gross negligence resulting in serious injury or death). In such cases, an individual is liable to imprisonment for 2 years. Under the NSW Act, where the conduct of a person with OHS duties causes the death of another person at any place of work, and the person is reckless as to the danger of death or serious injury, that person my be fined up to $\$ 165,000$, and/or be imprisoned for a period of up to 5 years. ${ }^{67}$

It is important to remember that maximum fines provided in the legislation may be substantially reduced where the offence is indictable but is prosecuted in a local or magistrates' court. Also, maximum penalties set by legislation do not give a realistic picture of the likely penalties on conviction. Research on penalties and sentencing generally for OHS offences in Victoria shows that average fines throughout the 1990 s were as little as $21.6 \%$ of the possible maximum. ${ }^{68}$ In NSW, fines over the

\footnotetext{
${ }^{66}$ In Victoria, two supervisors were successfully prosecuted for their ill-treatment of apprentices at their workplace, which included setting one alight, under s 25 of the OHS Act 1985 (Vic).

${ }^{67}$ OHS Amendment (Workplace Deaths) Act 2005 (NSW), Schedule 1.

${ }^{68}$ JOHNSTONE, supra $\mathrm{n} 37$, at 10 . The data does not separate out fines for individuals and corporations.
} 
period 1986 - 2003 averaged between 10 and 20 per cent of the maximum, with a penalty of more than $50 \%$ of the maximum being imposed in very few cases. ${ }^{69}$ The recent inquiry into the Western Australian legislation made similar findings.

Some state legislation provides some further penalty options eg publicity orders under s 115 of the NSW act and adverse publicity orders, orders to undertake improvement projects and release on giving a health and safety undertaking in the Victorian act.

\section{Critique OF THE INDIVIDUAL LIABILITY MOdELS}

\section{A The range of individuals who may face prosecution}

The liability provisions in the state statutes apply variously to 'directors', 'officers', 'executive officers' and 'persons concerned in the management' of the employer corporation. The 'responsible officer' model places liability on persons nominated or deemed 'responsible officers' for the purposes of the OHS provisions.

The term 'officer' is generally defined consistently with general corporations legislation, and may include directors, secretaries and executive officers, both de jure and de facto (see eg s 5 OHS Act 2004 (Vic)). The expression 'persons concerned in the management' of an employer corporation has a less certain meaning. Case law suggests that the phrase 'concerned in the management' is not confined to persons who have the central direction of the company's affairs. ${ }^{70}$ To be concerned in management, the person must however have some substantial degree of responsibility for the company's operations generally, or for a significant part of the business. ${ }^{71}$ It is acknowledged that individual responsibility and liability depends upon the manager's seniority and his or her capacity to deal with OHS issues:

...the greater the degree of responsibility within the corporate hierarchy and the greater the ability to rectify the problem the greater the degree of culpability which results. Once senior management becomes aware of the problem or once circumstances existed which should have resulted in management appreciating that there was a problem, the degree of culpability of the defendant increases accordingly. ${ }^{72}$

It is vital that officers and managers know in advance of their legal liabilities and this might be achieved by expanding the legislative definition of 'concerned in the management' to increase certainty about which managers may face liability.

\footnotetext{
${ }^{69}$ MCCALLUM et al, supra n 29, at paras 14-15.

${ }^{70}$ Commissioner for Corporate Affairs v Bracht, [1989] VR 821.

${ }^{71}$ Landeryou v Taylor, (1969) FLR 149.

${ }^{72}$ WorkCover Authority of NSW v Goodman Fielder Mills Ltd, Industrial Court of NSW, Marks J, 30 November 1994.
} 


\section{B What factors are important in assessing the efficacy of legislative provisions?}

The models need to be measured against some principles to determine their effectiveness. The statutory provisions should:

- make it clear that organizational responsibility for good OHS management rests with directors and senior management

- as far as possible promote a proactive approach to OHS in by directors and senior management in organizations

- recognize the interrelationship between breaches of duty by the organization and management failure

- provide for director/manager liability only with proof of individual fault (although casting the proof of defences like 'due diligence' on the officer is not contrary to this principle)

- provide penalties that reflect the seriousness of OHS breaches and provide for a sufficiently deterrent effect

- be prosecuted appropriately, to ensure in particular a general deterrent effect. $^{73}$

\section{The deemed contravention, subject to defences like due diligence model}

The 'deemed contravention, subject to defences like due diligence' form of liability exemplified by s 26 of the Occupational Health and Safety Act 2000 (NSW) is preferred of the existing models, although some there are difficulties with it, particularly with respect to ensuring the accountability of directors and managers of larger companies.

There are a very small number of reported cases in the NSW jurisdiction from which some tentative conclusions can be drawn. First, the reported cases involve small companies in which the director or manager charged was directly involved in the day to day business operations, and the injuries caused (or breach of safety) were very serious. ${ }^{74}$ It is much more common for 'operational' directors in small companies to be prosecuted than those in larger organisations:

...it appears that directors and managers of small to medium-sized companies may face greater exposure under the provisions of s 26 of the Act. This arises in part because of their greater involvement in the operational aspects of a corporation's activities - as such, their individual acts or omissions are

\footnotetext{
${ }^{73}$ A number of these principles are set out and further elaborated upon in MCCALLUM et al, supra n 29, at paras $192-214$

${ }^{74}$ See eg Workcover Authority of New South Wales v RJ Waugh, (1995) 59 IR 89 (New South Wales Industrial Relations Commission, 1995); Workcover Authority of New South Wales v CI \& D Industries Pty Ltd, [1995] NSWIRC 220; Inspector Brian Dell v Vidler, [2003] NSWIRComm 267.
} 
more apparent than in the case of larger corporations, which may have complex organisational structures in place. ${ }^{75}$

There is some evidence that smaller companies may, overall, have poorer OHS standards, ${ }^{76}$ but it is not clear whether authorities take this into account in determining the general deterrent effect of prosecuting small as opposed to big business. It may be that it is simply more difficult to successfully prosecute larger corporations, particularly if organisations wish to obfuscate individual liability. Thus the statutory provisions possess the same weakness as the general criminal law, which also makes prosecuting larger companies more problematic than smaller ones. ${ }^{77}$

The NSW Commission hearing these matters does not take an overly narrow approach to interpreting the concept of due diligence (the main defence litigated in the cases); it recognises that OHS requires a systematic approach to assessing and dealing with risk, and that due diligence on the part of management involves ensuring proper safety systems are in place. In WorkCover Authority of NSW (Insp Tyler) $v$ John Anthony Brown, Brown was the director and senior on-site representative of a demolition contracting company. Although absent on the day of the safety breach (collapse of a scaffold on which demolition work was carried out), as on-site manager, Brown was in a position to influence the company's conduct in respect of all matters going to the alleged contraventions. The system of work was manifestly unsafe and the director failed to display all due diligence. ${ }^{78}$ In WorkCover Authority of NSW (Insp Blake) v Dilario, the magistrate observed that the company had laid down a safe system of work and had delegated certain supervisory responsibilities to competent and trusted persons. The directors regularly visited the site and:

...exercising due diligence would have observed [that] the system ... was not being observed. They had laid down a safe system, they were in a position to ensure the system was enforced but they failed to ensure the system was maintained. ${ }^{79}$

The due diligence defence succeeded however in WorkCover Authority of NSW (Insp Dowling) v Barry John Coster. Here the evidence indicated that the director took a proactive approach to health and safety on site during the shopping centre renovations. He was an 'active and receptive participant' in the affairs of the site safety committee. He presided over safety personnel of whom he required vigilance and personally inspected the safety fencing to ensure it was adequate. He ensured that there was a proper response taken to the prohibition notices placed on the site by WorkCover inspectors. The safety breach occurred in spite of these precautions.

\footnotetext{
${ }^{75}$ Wendy ThOMPSON, Understanding THE NSW OCCUPATIONAL HEALTH AND SAFETy ACT 82 (3 ${ }^{\mathrm{RD}}$ ed 2001).

${ }^{76}$ Fiona Haines, Corporate Regulation: Beyond Punish OR PERSUAde 20-21 (1997).

${ }^{77}$ HALL, JOHNSTONE, RIDGEWAY, supra n 3, at 35-36.

${ }^{78}$ THOMPSON, supra $\mathrm{n} 75$, at 83.

${ }^{79}$ CIMC matter no 96/1307-1308, Miller CIM, cited in THOMPSON, supra n 75, at 84-85.
} 
The concept of 'due diligence' is generally well-known in the business community as a measure of compliance with a range of statutory responsibilities and provides an objective measure of adherence to standards. The limited case law does suggest that due diligence in the OHS context means a minimum standard of behaviour involving the proactive development of a safe system of work that meets the statutory duty to provide, so far as is reasonably practicable, a workplace that is safe and without risks to health, plus adequate supervision and monitoring ensuring that the system is properly carried out. ${ }^{80}$ Due diligence also requires that directors and managers should immediately and personally react when they have notice that the system has failed. ${ }^{81}$ The Industry Commission endorsed the model as the preferred one for managerial liability under OHS laws. There is little doubt, however, that positive guidance to directors and managers on what due diligence requires as a matter of day-to-day practice in OHS is useful and important to the development maintenance of proper safety standards.

The burden of proof is properly cast on the defendant officer, on the balance of probabilities. The fact that a director or senior manager may need to demonstrate due diligence is more likely to promote compliance with the legislation - officers and senior managers have a stronger motivation to ensure that their companies have proper and transparent policies in place for the assessment of risk and proper plans for risk elimination and minimisation.

\section{Officer causes corporation's breach by failing to take reasonable care}

Whilst in theory an improvement on the officer provisions in the 1985 Act, these new provisions in s 144 of the OHS Act 2004 (Vic) cast a very substantial burden on the prosecution. It will be necessary to prove both the causal link between the officer's lack of reasonable care and the corporation's offence, and to establish what, in all the circumstances, 'reasonable care' might involve. The factors to be taken into account in determining reasonable care include 'what the officer knew about the matter concerned' and 'whether the contravention by the body corporate is also attributable to an act or omission of any other person'. It is submitted that such considerations encourage an approach that considers the immediate cause of safety breaches rather than also considering the importance of proper risk management systems overall and management responsibility for such systems. ${ }^{82}$ They may also enable managers in large companies to put cursory 'paper systems' of OHS management in place, and blame supervisors or employees for the failure to implement them. It is suggested that the chances of establishing guilt in all but the most serious cases of negligence by working directors in small companies is slight under this formulation.

\footnotetext{
${ }^{80}$ Universal Telecasters (Queensland) v Guthrie, (1978) 18 ALR 531 (Federal Court of Australia, 1978). ${ }^{81}$ THOMPSON, supra n 75, at 84- 85. R v Bata Industries Ltd , 9 OR (3d) 329; 1992 Ont Rep LEXIS 223 (Ontario Court Provincial Division, 1992).

${ }^{82}$ The importance of a systematic approach to the causes of workplace accidents was addressed by Neil Gunningham in SAFEGUARDING THE WORKER (1986) and GUNNINGHAM \& JOHNSTONE, supra n 45.
} 


\section{E 'Consent, connivance, wilful neglect'}

The 'consent or connivance' formulation used in the Western Australian and NT provisions is unjustifiably narrow and fails to strike a good balance between corporate and individual liability. It fails to recognise that management responsibility for OHS should extend more widely than merely avoiding deliberate connivance in, or consent to, the corporation's offence, if deaths and injuries are to be minimised. The terms 'consent, connivance or wilful neglect' mean that liability will be established only in the most egregious of circumstances. ${ }^{83}$ Such a formulation is insufficient to deter lax management practices in risk assessment and implementation of safety standards that fall short of gross negligence but which contribute to deaths and injuries at work.

\section{F Responsible officer}

The requirement in the South Australian provisions that the responsible officer 'take reasonable steps to ensure compliance' by the employer potentially provides for managerial liability in wider circumstances than consent or connivance. However, the legislation gives no guidance on what 'reasonable steps' might be and a code of practice or guidance note would be necessary.

The Tasmanian provisions give greater guidance by using concepts of 'due diligence' and 'lack of control', but the provisions are weakened by the officer's contravention being a 'failure to perform' rather than the legislation imposing a positive duty on those individuals who have the capacity to ensure compliance.

Vesting legal liability in a nominated 'responsible officer', as in the Tasmanian provisions, can work well only if there can be certainty that such a nominee will be given adequate resources to meet the statutory requirements of the position. The existence of a statutory position of 'responsible officer' might in some organisations be an excuse to divert responsibility away from those with the real authority to deal with OHS properly - the board and the CEO. The Tasmanian Act requires the employer to ensure that the responsible officer has sufficient authority to perform the employer's duties under the Act. It deems the CEO to be responsible in the event there is no appointment for the purposes of the Act. Unless a responsible officer with express statutory functions has the power and resources to ensure safety is a top priority, the post itself 'could easily prove to be a poisoned chalice'. ${ }^{84}$

\footnotetext{
${ }^{83}$ For a recent discussion of the wording, see AB Oxford Cold Storage v Arnott , [2003] VSC 452 (Supreme Court of Victoria, 2003), in which the Supreme Court overturned the guilty finding of the Magistrate against a director of the company. See also CHRIS MAXWELL QC, REVIEW OF THE OCCUPATIONAL HEALTH AND SAFETY ACT 1985 (VIC) para [758] (2004).

${ }^{84}$ JAMES GOBERT AND MAURICE PUNCH, RETHINKING CORPORATE CRIME 271 (2003).
} 


\section{G A proposal for an improved model of individual liability}

McCallum et al proposed a new provision to improve manager liability under OHS legislation. The proposal is based on three principles. The first is the introduction of a code of practice with statutory force. The purpose of the code would be to 'both define and impose obligations on senior management personnel thereby encouraging and indeed mandating a proactive approach to safety and which would have the effect of limiting avenues of escape from liability' ${ }^{85}$ The deeming provision in s 26 of the NSW act would remain, as would the defences, with reliance on the defences 'limited and circumscribed by the Code of Practice and demonstrated compliance by directors and managers with their obligations under the Code' ${ }^{86}$

The clear advantage of this proposed model is that is accompanied by detailed written advice that would be designed to promote a proactive approach to OHS management and would make it less likely that the directors and managers of larger organizations could escape liability.

\section{$\mathrm{H} \quad$ Individual liability in practice and the need for more prosecutions of individuals}

Data indicates that very few individuals are prosecuted overall. Johnstone estimates that only $15 \%$ of total prosecutions in Australia (which themselves represent only a tiny proportion of breaches overall) in the 1990s were of individuals. ${ }^{87}$ In Victoria, for example, in the period 1990 - 1995, the total number of individual prosecutions was 14, and this figure includes offences other than the officer offence (such as hindering inspectors). ${ }^{88}$ New South Wales appears to prosecute more individuals than other states.

Anecdotal evidence about the types of cases in which directors and managers are prosecuted can be gleaned from publications like the Victorian WorkCover Authority's annual prosecutions publication ${ }^{89}$ and from the cases that are now available online. The individuals prosecuted in NSW, the busiest state jurisdiction, are managing directors, other senior managers or senior employees with a supervisory role, whose acts or omissions have contributed directly to the safety breach. This is consistent with the policy of the NSW WorkCover Authority to prosecute individual defendants taking into account who is 'primarily responsible' for the alleged offence, what was the culpability of the proposed defendant and the effectiveness of

\footnotetext{
${ }^{85}$ MCCALLUM et al, supra n 29, para 192

${ }^{86}$ Id. at para 191.

${ }^{87}$ JOHNSTONE, supra n 37, 8.

${ }^{88}$ Virginia Whalen, Individual Liability of Corporate Officers, and Corporate Manslaughter and Other Offences: Overview of Provisions ad Statistics, in NEW DIRECTIONS IN OCCUPATIONAL HEALTH AND SAFETY PROSECUTIONS 8 (Richard Johnstone ed., 1996).

${ }^{89}$ See <www.workcover.vic.gov.au/pubs> (last visited 11 July 2005).
} 
any court order that might be made against the proposed defendant..$^{90}$ As has been pointed out above, however, these individuals are far more likely to be involved in small companies.

\section{NON-Legal INITIATIVES For IMPROVING Compliance}

This paper argues for stronger legal mechanisms to promote compliance with OHS laws by directors and senior managers. It is important to recognise however that the OHS compliance systems implemented by state government authorities are based heavily on achieving compliance through encouragement, persuasion and advice to dutyholders. Legal sanctions are at the top of the 'compliance pyramid' and used as a last resort against those for whom persuasion has proven to be ineffective, or in the most serious cases of safety breaches (eg where deaths or serious injuries result).

Non-legal approaches should be used as part of overall compliance strategies where there is evidence that they might contribute to achieving better compliance with OHS requirements at board and senior management level. Certainly voluntary approaches to improve corporate governance and to promote corporate social responsibility have been popular with many, although voluntary compliance also has its strong critics. ${ }^{91}$

Promoting the role of board directors in OHS has recently been a focus of activity by the Health and Safety Executive and the Health and Safety Commission in the United Kingdom. The success of the HSE may provide guidance for other jurisdictions like Australia in fostering greater board commitment as part of strategies to improve OHS compliance in organisations. As part of its Revitalising Health and Safety strategy, the HSE has developed a voluntary code of practice on directors' responsibilities for health and safety. This step was taken to foster the HSC's goal of 'promoting and encouraging greater corporate responsibility and accountability for occupational health and safety'. ${ }^{92}$ The HSC has actively promoted use of the code through conference presentations, press coverage and holding discussions with the most senior executives and board members in top UK companies. It is also promoting the inclusion of OHS reporting to shareholders in company annual reports.

The guidance is designed to impress on board members of all types of organisations that effective management of health and safety risks is an essential part of effective corporate governance. It is aimed at directors and all members of top-level man-

\footnotetext{
${ }^{90}$ WorkCover Authority of New South Wales, Policy And Prosecution Guidelines (2004), $<$ www.workcover.nsw.gov.au>, 22 (last visited October 2004).

${ }^{91}$ See eg, S Gregg, Stakeholder Theory: What it Means for Corporate Governance, POLICY, WINTER (JUN-AUG) 2001, <www.cis.org.au/Policy/winter01/polwin01-7.htm>, where it is argued that stakeholder theory is an incoherent and implausible guide to how corporations act or should act.

92 HEALTH AND SAFETY COMMISSION, CORPORATE RESPONSIBILITY AND ACCOUNTABILITY FOR OCCUPATIONAL HEALTH AND SAFETY: A PROGRESS REPORT ON HSC/E INITIATIVES AND MEASURES, (24 September 2003), available at <www.hse.gov.uk>.
} 
agement who provide strategic leadership, direction and oversight and set the policy on health and safety. The guidance sets out how effective management of OHS risks can maximise the well-being and productivity of workers, prevent deaths and injuries, improve the organisation's reputation, avoid damaging effects on turnover and profitability, encourage better relationships with contractors, and minimise the likelihood of prosecution and penalties. It consists of 5 'action points', as follows:

1. The board needs to accept formally and publicly its collective role in providing health and safety leadership in its organisation

2. Each member of the board needs to accept their individual role in providing health and safety leadership for their organisation

3. The board needs to ensure that all board decisions reflect its health and safety intentions, as articulated in the health and safety policy statement

4. The board needs to recognise its role in engaging the active participation of workers in improving health and safety, and

5. The board needs to ensure that it is kept informed of, and alert to, relevant health and safety risk management issues. The HSC recommends that boards appoint one of their number to be the 'health and safety director'.

The guidance goes on to explain what practical steps can be taken to fulfil each of the action points, as well as summarising the company's legal responsibilities under the Health and Safety at Work Act 1974 and providing sources of further information.

Recent research shows an increase in the number of companies that have boardlevel health and safety management arrangements since the introduction of the guidance. There had been an increase of $8 \%$ in the percentage of surveyed companies having direction of OHS from board level since the promulgation of the guidance, with a total of $66 \%$ of companies overall having these arrangements. These arrangements are more common in larger firms, with $75 \%$ of the top 350 corporations having specific board level direction and oversight. There was an increase in the number of respondents who believed that board level direction of OHS represented best practice. ${ }^{93}$

Given the success of the British initiative, similar education programs are worthy of consideration by OHS authorities around Australia, or by the National Occupational Health and Safety Commission as a cost-effective adjunct to existing measures designed to promote OHS compliance in the absence of enforceable codes of practice on director and manager responsibilities. There are some initiatives in the states to at least provide more guidance specifically aimed at senior managers, with the Victorian government undertaking to provide clear guidance material to senior officers on the new provisions in the OHS Act 2004 (Vic). ${ }^{94}$

\footnotetext{
${ }^{93}$ Health AND SAFETy EXECUTIVE, HeAlth AND SAFETY RESPONSIBILITIES OF COMPANY DIRECTORS CONTRACT RESEARCH REPORT (2003), at <www.hse.gov.uk/pubs>. The research was based on surveys of more than 400 companies and public sector organizations with more than 250 employees.

94 The Hon Rob Hulls MP, Occupational Health and Safety Bill 2004 Second Reading SPEeCh, HANSARd, PARLiament OF Victoria Legislative AsSEMBly 1764 (18 November 2004).
} 


\section{CONCLUSIONS}

Given the importance to the community and individuals of healthy and safe workplaces, good regulatory systems and effective legal and other mechanisms that promote effective OHS management are paramount. Negligence law and OHS regulation place the principal legal obligation to provide and maintain a healthy and safe workplace on the employer. This is a rational approach that is justified by the control of the employer over the business enterprise and how it is conducted.

Although the employer is the principal dutyholder, there are very good arguments for the imposition of more specific legal responsibilities on directors and senior managers of companies. The common law of negligence and the fiduciary obligations of directors and senior employees provide little if any scope for individual legal liability, although the current inquiry by the Parliamentary Joint Committee on Corporations and Financial Services into corporate responsibility will enliven the debate about whether directors' duties ought to be expanded to encompass other stakeholders, such as employees. The general criminal law provides very little cope for accountability, especially where a death or serious injury occurs as a result of an omission rather than a positive act. Industrial manslaughter provisions, with their heavier penalties and the possibility of imprisonment, provide an alternative and potentially effective source of individual liability, although the offences are very strictly confined and likely to be prosecuted exceedingly rarely.

We must continue to rely on OHS legislation as the main source of individual liability. Whilst we must acknowledge that the issue of the deterrent effect of criminal provisions on individuals within corporations is a complex issue, there is evidence that the risk of individual prosecution and punishment have a deterrent effect on some corporate managers, and this ultimately will benefit workers. Importantly, the symbolic, denunciatory value of individual liability provisions should not be undervalued. Accordingly, there is an important place for individual liability in OHS regulation.

Given that OHS is a state responsibility, it is unsurprising that individual liability takes several different legislative forms. Of the current formulations, the most effective is the one that deems officers and managers to have committed an offence when the corporation has done so, subject to defences including due diligence. This provides a readily understandable, effective and appropriate standard of individual liability, especially as the concept of due diligence enables objective measures of conduct to be used. ${ }^{95}$ Ultimately, a statutory standard that provides detailed guidance on how directors and managers can ensure a proactive, systems-based approach to OHS management in organisations is the best formulation.

\footnotetext{
${ }^{95}$ The due diligence model was endorsed by the Industry Commission, 1995.
} 
Prosecution of individual officers who breach their due diligence obligations, or who demonstrate recklessness or gross negligence in safety matters, needs greater emphasis in the compliance regime, especially where a worker is killed or seriously injured. It is acknowledged that such a statement does not sit well with the 'persuade, not punish' approach that is likely to continue dominate OHS compliance strategies. Serious questions do need to be asked, however, about whether current enforcement policies, including the number of prosecutions and the types of duty holders prosecuted, are optimum. ${ }^{96}$ It appears that in enforcement the target is the organisation itself rather than the individuals that run them; those directors and managers that are prosecuted are likely to work for smaller companies. This may be justified if smaller companies have poorer OHS compliance overall, but whether smaller companies do is not certain. These decisions may be affected by practical matters like the relative difficulty in amassing evidence against an individual in an organisation compared to the organisation itself, and the relative ease in amassing evidence against a working director in a small company compared to a director or senior manager in a larger company that has a more complex organisational structure and more delegation of OHS responsibilities through several levels of management. Magistrates and judges may also be more willing to brand a corporation a criminal than to brand individuals criminals for regulatory breaches and, when they do, to generally lightly penalise even very culpable individuals.

If we acknowledge the practical reality that non-legal strategies continue to dominate in OHS compliance programs, we can perhaps learn something valuable from the British experience that voluntary guidance to companies on the importance of boards and senior management commitment to proactive OHS management programs can achieve positive results. The Australian OHS agencies could perform a very useful role in promoting voluntary board commitment to OHS and compliance with statutory duties, learning from the strategies of the Health and Safety Executive in Britain.

It is hoped that, ultimately, a combination of stronger individual liability provisions, better legal enforcement and voluntary compliance will lead to fewer deaths and injuries of Australian workers.

\footnotetext{
${ }^{96}$ GUNNINGHAM \& JOHNSTONE, supra n 45, ch 6.
} 